\title{
Okoliczności i postawa NATO wobec polityki militarnej Rosji na Ukrainie
}

\section{Wprowadzenie}

Działania zbrojne Rosji na Ukrainie i ich konsekwencje stanowią najpoważniejszy kryzys po zimnej wojnie, jakiemu musi stawić czoła Sojusz Północnoatlantycki. Kryzys na Ukrainie nie dotyczy bowiem tylko bezpieczeństwa tego państwa, ale także całego regionu. NATO musi z determinacją reagować na działania militarne i prowokacje prowadzone przez Rosję wobec państw Europy Środkowo-Wschodniej. Przede wszystkim musi zapewnić bezpieczeństwo swoim członkom zlokalizowanym na wschodniej flance Sojuszu, ponieważ od tego zależy jego wiarygodność i tym samym zasadność dalszego istnienia (Webber, 2016, s. 1). Nie bez znaczenia jest również wsparcie dla samej Ukrainy, która od ponad dwóch dekad aktywnie współpracowała z Sojuszem i aspirowała do członkostwa w organizacji.

Celem artykułu jest analiza i ocena okoliczności i postawy NATO wobec polityki militarnej Rosji na Ukrainie. Główny problem badawczy zawarty jest w pytaniu, czy reakcja NATO była odpowiednia i wystarczająco zdecydowana, żeby zabezpieczyć przed Rosją państwa wschodniej flanki NATO, skutecznie zniechęcić ją do zaniechania prowokacyjnych działań wobec członków Sojuszu oraz zmusić do zmiany polityki wobec Ukrainy? Przewodnią tezą artykułu jest stwierdzenie, że NATO potwierdziło, że jego tradycyjna funkcja w postaci obrony państw członkowskich i odstraszania potencjalnych agresorów pozostaje fundamentem istnienia Sojuszu. Charakter podjętych działań na rzecz zabezpieczenia wschodniej flanki NATO ma zarówno wymiar symboliczny, jak i praktyczny. Przede wszystkim mają one uzmysłowić Rosji, że gdy zaistnieje taka konieczność, to Sojusz będzie kolektywnie bronił swoich członków. W wymiarze praktycznym podjęte wzmocnienia wojskowe są istotne, szczególnie dla dysponujących niewielkim potencjałem militarnym państw bałtyckich. Ich skala nie jest jednak wystarczająca do szybkiego odparcia ewentualnej agresji zbrojnej o wysokiej intensywności. Podjęto jednak szereg działań na rzecz sprawniejszego przegrupowania w region większych formacji zbrojnych NATO, jak również ochrony państw NATO przed atakami hybrydowymi. Reakcja NATO nie jest jednak wystarczająca, aby zmusić Rosję do odwołania aneksji Krymu i zakończenia wspierania separatystów w Donbasie. Podczas pisania artykułu skorzystano z metody analizy źródeł tekstowych. 


\section{Relacje między NATO i Rosją po zimnej wojnie}

Po zakończeniu zimnej wojny relacje między NATO i Rosją zainicjowane zostały wraz z wstąpieniem Rosji w 1991 roku do nowo powstałej Rady Współpracy Północnoatlantyckiej (North Atlantic Cooperation Council - NACC), która miała być forum konsultacji między NATO a państwami partnerskimi. W 1994 roku Rosja wstąpiła do zaproponowanego przez NATO programu Partnerstwo dla Pokoju (Partnership for Peace - PfP), rozpoczynając tym samym praktyczną współpracę z Sojuszem. Ważnym jej przejawem było porozumienie się w 1995 roku w kwestii do uczestnictwa Rosji w misji NATO w Bośni i Hercegowinie oraz implementacji Traktatu o siłach konwencjonalnych w Europie (Treaty on Conventional Forces in Europe - CFE) z 1992 roku.

Dalszy postęp w relacjach NATO-Rosja przyniósł rok 1997. W maju NACC został przekształcony w Radę Partnerstwa Euroatlantyckiego (Euro-Atlantic Partnership Council - EAPC), w którym Rosja również zaczęła aktywnie uczestniczyć. Tego samego roku stworzono formalne podstawy dla współpracy dwustronnej między NATO i Rosją. Partnerzy podpisali „Akt stanowiący o podstawach wzajemnych stosunków, współpracy i bezpieczeństwa". Głównym celem współpracy miało być stworzenie strefy stałego pokoju na obszarze euroatlantyckim. W dokumencie powołano do życia Stałą Radę Współpracy NATO-Rosja (NATO-Russia Permanent Joint Council - PJC). W jej ramach miano konsultować najważniejsze kwestie bezpieczeństwa, w tym zapobiegania i wygaszania konfliktów, kontroli zbrojeń oraz walki ze zjawiskami terroryzmu międzynarodowego i rozprzestrzeniania broni masowego rażenia (Founding, 1997). Prezydent Stanów Zjednoczonych Bill Clinton (01.1993-01.2001) stał ówcześnie na stanowisku, że pewnego dnia także Rosja mogła stać się pełnoprawnym członkiem NATO. Pogrążona w kryzysie Rosja pod rządami prezydenta Borysa Jelcyna (07.1991-12.1999) otwarta była na zacieśnianie współpracy z NATO. Liczyła przy tym, że Sojusz uszanuje jej strategiczne interesy i strefy wpływów (Kaplan, 2004, s. 144).

W 1999 roku relacje między NATO i Rosją uległy znacznemu pogorszeniu. Można stwierdzić, że rozpoczął się wtedy długotrwały trend spadkowy we współpracy między partnerami (Flockhart, 2016, s. 154). Wśród głównych powodów było rozszerzenie NATO o byłe państwa Układu Warszawskiego, operacja wojskowa NATO w Kosowie i wybuch drugiej wojny w Czeczenii (Bouchet, 2015, s. 83). Mimo, że Borys Jelcyn do końca sprzeciwiał się rozszerzeniu NATO na wschód, to Moskwa nie miała wystarczającej siły i determinacji do powstrzymania tego procesu (Bandeira, 2017, s. 23). Również działania NATO w Kosowie stanowiły ingerencją w strefie wpływów Rosji, ponieważ istotnie godziły w interesy zaprzyjaźnionej z Rosją Serbii. W Czeczenii NATO z oczywistych względów nie ingerowało, jednak jego przywódcy zdecydowanie krytykowali bezlitosne działania Rosji wobec chcącej wybić się na samodzielność republiki.

W celu odbudowy stosunków i koordynacji współpracy w walce z międzynarodowym terroryzmem w maju 2002 roku utworzono nową platformę konsultacji w postaci Rady NATO-Rosja (NATO-Russia Council - NRC). Próba ocieplenia stosunków nie udała się, ponieważ już w marcu 2003 roku poważnie one ucierpiały z powodu 
interwencji w Iraku koalicji państw zachodnich pod amerykańskim przywództwem. Jeszcze większe napięcia wywołało zaproszenie do członkostwa w Sojuszu państw bałtyckich. Rosja liczyła, że NATO ograniczy swój rozwój do państw Europy Środkowej. Włączenie w 2004 roku do NATO pierwszych byłych republik radzieckich i utrzymywanie polityki ,otwartych drzwi” dla kolejnych, w tym Ukrainy, przekreśliło nadzieję Moskwy na poszanowanie przez Sojusz jej strefy wpływów. Polityka NATO pokazała, że Zachód nie godził się na wytyczenie nowych linii podziału w Europie lub pozostawienie w niej ,szarych stref bezpieczeństwa” (Behnke, 2013, s. 121).

Państwa NATO zaangażowały się we wsparcie tzw. ,kolorowych rewolucji” w Europie Wschodniej, tj. „Rewolucji róż” w Gruzji z 2003 roku i „Pomarańczowej rewolucji” na Ukrainie z 2004 roku (Lindley-French, Macfarlane, 2007, s. 108). W Rosji przewroty te interpretowano, jako konsekwencję ingerencji Zachodu motywowanej chęcią ograniczenia wpływów Rosji w regionie (MacFarlane, 2008, s. 40). Państwa NATO przekonywały z kolei Rosję, żeby nie ingerowała w wewnętrzne sprawy tych państw, w tym procesy wyborcze, twierdząc, że może ona więcej na tym stracić, niż zyskać (Treverton, 2016, s. 53). W wyniku rewolucji na Ukrainie i w Gruzji obalono prorosyjskie reżimy, po czym zaczęły one aspirować do Planu działania na rzecz członkostwa w NATO (NATO Membership Action Plan - MAP). Stany Zjednoczone i państwa Europy Środkowo-Wschodniej popierały te aspiracje, jednak na ich drodze stanęły państwa tzw. starej Europy, w tym Niemcy i Francja, które nie chciały prowokować Rosji (Lagadec, 2012, s. 91).

Włączenie Ukrainy i Gruzji do NATO spowodowałoby oskrzydlenie z dwóch stron portu w Noworosyjsku - jedynego ówcześnie rosyjskiego portu na Morzu Czarnym. Byłoby to poważne zagrożenie nie tylko dla jej interesów geopolitycznych, ale również gospodarczych, zważywszy na jego znaczenie dla transportu surowców energetycznych (Gardner, 2005, s. 139). Moskwa stała na stanowisku, że dalsze rozszerzenie NATO na Wschód, albo umieszczenie w jej bliskim sąsiedztwie instalacji wojskowych Sojuszu, doprowadzi do nowych podziałów w Europie i wzrostu ryzyka wybuchu na kontynencie wojny wysokiej intensywności (Leichtova, 2016, s. 53). Aby powstrzymać ten proces w sierpniu 2008 roku Rosja wsparła separatystów z Osetii Południowej i Abchazji wchodząc w bezpośredni konflikt zbrojny z Gruzją. W odpowiedzi NATO zawiesiło formalną współpracę z Rosją w ramach NRC do wiosny 2009 roku i bezskutecznie zażądało odwołania przez Moskwę uznania niepodległości tych republik (Relations with Russia).

Pod koniec pierwszej dekady XXI wieku nastąpiło względne ustabilizowanie stosunków między NATO i Rosją. Spowodowane było to między innymi zaproponowanym przez administrację prezydenta Baracka Obamę (01.2009-01.2017) „resetem” w stosunkach między USA i Rosją. Ocieplenie nie trwało jednak długo, a do jego zakończenia doprowadziły wydarzenia „Arabskiej Wiosny”. Wbrew stanowisku Rosji operacja NATO w Libii z 2011 roku nie ograniczyła się tylko do ochrony ludności cywilnej, ale również przyczyniła się do zmiany reżimu politycznego w tym państwie. Rosja uznała to za sprzeniewierzenie się rezolucji Rady Bezpieczeństwa ONZ nr 1973 i oszukanie społeczności międzynarodowej (Widmaier, 2015, s. 122). Sprzeczne podejście NATO i Rosji do wydarzeń „Arabskiej Wiosny” widoczne było również w stosunku do innych państw, w tym głównie Syrii. 
Bardzo poważnym problemem w relacjach między NATO i Rosją jest również forsowany przez Stany Zjednoczone program tarczy antyrakietowej. Rosja stanowczo sprzeciwiała się umiejscowieniu przez Stany Zjednoczone elementów tego systemu w sojuszniczych państwach z Europy Środkowej. Uważała to za naruszenie równowagi strategicznej między mocarstwami i kolejny czynnik destabilizujący relacje między NATO i Rosją. Waszyngton nie odstąpił jednak od realizacji programu, a w ostatnich latach został on włączony do wspólnych działań NATO.

\section{Relacje między NATO i Ukrainą po zimnej wojnie}

Od ogłoszenia niepodległości w sierpniu 1991 roku Ukraina nie sprzeciwiała się rozszerzeniu NATO na Wschód (Ponsard, 2007, s. 98). Nie oznacza to, że jej władze nie wyrażały obaw, że proces ten może doprowadzić do odtworzenia zimnowojennych podziałów w Europie (Zięba, 2013, s. 207). Tego samego roku Ukraina wstąpiła do NACC, a od 1997 roku kontynuowała współpracę wielostronną z NATO i jego państwami partnerskimi w ramach EAPC. W lutym 1994 roku Kijów, jako pierwsza stolica państwa postradzieckiego, podpisał porozumienie ramowe na temat uczestnictwa Ukrainy w PfP. W grudniu tego samego roku podpisał Memorandum Budapesztańskie, w którym zdecydował się przekazać Rosji broń jądrową w zamian za gwarancje bezpieczeństwa ze strony Stanów Zjednoczonych, Rosji i Wielkiej Brytanii. Decyzja ta została z zadowoleniem przyjęta przez partnerów z NACC (Terzuolo, 2006, s. 28).

Wydarzenia 1997 roku były przełomowe dla pogłębienia stosunków między NATO i Ukrainą. Na szczycie NATO w Madrycie z 8-9 lipca 1997 r. podpisano „Kartę szczególnego partnerstwa między NATO i Ukrainą". Powołała ona do życia komisję NATOUkraina (NATO-Ukraine Commission - NUC) dedykowaną pogłębionym negocjacjom w zakresie bezpieczeństwa, współpracy i wsparcia reform sektora bezpieczeństwa Ukrainy (Charter, 1997). Zacieśnienie współpracy z Ukrainą miało zrównoważyć zainicjowane tego samego roku specjalne relacje między NATO i Rosją. W tym okresie NATO realizowało już politykę „otwartych drzwi”, która dotyczyła także państw wchodzących wcześniej w skład Związku Radzieckiego. Wraz z powołaniem NUC rozpoczęły się pierwsze rozmowy między NATO a Ukrainą na temat możliwości perspektywicznego wstąpienia tego państwa do Sojuszu (Dumbrell, 2009, s. 129).

W koncepcji strategicznej NATO przyjętej na szczycie w Waszyngtonie z 23-25 kwietnia 1999 r. odwołano się do specjalnych relacji Sojuszu z Ukrainą (Orfy, 2011, s. 72). NATO potwierdziło swoje zobowiązanie do wsparcia suwerenności, integralności terytorialnej i rozwoju sektora bezpieczeństwa Ukrainy. Zapowiedziało również działania na rzecz pogłębiania relacji z tym państwem (The Alliance's, 1999). Ukraina była dla NATO jednym z kluczowych partnerów w rozszerzaniu obszaru bezpieczeństwa we Wschodniej Europie (Orfy, 2011, s. 81). W odróżnieniu od relacji NATO z Rosją, współpraca z Ukrainą nie ucierpiała z powodu wydarzeń 1999 roku. Wręcz przeciwnie, oddelegowanie przez Ukrainę kontyngentu wojskowego do misji NATO w Kosowie zwiększyło zaufanie Sojuszu wobec partnera (Terzuolo, 2006, s. 67). Podczas szczytu NATO w Pradze z 21-22 listopada 2002 r. Kijów podpisał „Plan działania NATO” („NATO Action Plan”) i zapowiedział wsparcie Sojuszu w walce z między- 
narodowym terroryzmem (Hansen, Toft, 2009, s. 56). Ukraina wysłała kontyngenty wojskowe zarówno do Afganistanu, jak i Iraku, gdzie wspierała wysiłki stabilizacyjne państw NATO (Aaltola, Käpylä, 2014, s. 196). Ukraina wspierała również inne misje NATO, na przykład na przełomie 2005 i 2006 roku wynajmowała dla NATO samoloty transportowe na potrzeby realizacji misji ratowniczej i humanitarnej po trzęsieniu ziemi w Pakistanie (Hallams, 2010, s. 122). NATO z kolei wspierało współpracę Ukrainy z państwami wschodniej flanki Sojuszu, przede wszystkim z Polską, która stała się głównym adwokatem jej członkostwa w Sojuszu (Gardner, 2005, s. 130).

22 lutego 2005 r. na specjalnym szczycie NATO-Ukraina nowo zaprzysiężony prezydent Wiktor Juszczenko (01.2005-02.2010) zapowiedział dążenie Ukrainy do członkostwa w NATO, a w okresie przejściowym pełnego wykorzystania istniejących mechanizmów współpracy. Oczekiwania te zostały pozytywnie przyjęte przez członków Sojuszu (Terzuolo, 2006, s. 141). Tego samego roku NATO i Ukraina zainicjowały ,zintensyfikowany dialog” na rzecz wzmożenia wysiłków integracyjnych. Decyzja ta zaktywizowała jednak przeciwników tego procesu zarówno na Ukrainie, jak i w Rosji (Herd, 2013, s. 73). Na przełomie maja i czerwca 2006 r. na Krymie odbyły się demonstracje przeciwko realizowanym w ramach PfP wspólnym ćwiczeniom armii ukraińskiej i NATO „Morska Bryza 2006” („Sea Breeze 2006”) (Gardner, 2005, s. 136). Ćwiczenia miały polegać na obronie Krymu przed inwazją państwa totalitarnego, co rodziło skojarzenia z obroną przed Rosją. Opór ten nie dziwił, ponieważ ponad połowa mieszkańców Krymu postrzegała NATO za zagrożenie dla ich bezpieczeństwa (Interfax-Ukraine, 2011). W tym samym czasie rosyjski „Gazprom” odciął dostawy gazu na Ukrainę, co było konsekwencją nieudanych negocjacji w kwestii tranzytu surowca przez to państwo. Tak zdecydowane działanie Rosji spotkało się z krytyką ze strony państw NATO. Ponadto Polska zainicjowała pracę w ramach Sojuszu nad długoterminowym rozwiązaniem problemu uzależnienia Europy od dostaw surowców energetycznych z Rosji (Cornell, 2013, s. 192).

Podczas szczytu NATO w Bukareszcie z 2-4 kwietnia 2008 r. Stany Zjednoczone i Polska zabiegały o szybkie włączenie Ukrainy, a wraz z nią Gruzji, do Sojuszu (Braun, 2008, s. 63). Nie udało się wtedy jednak osiągnąć porozumienia w kwestii zakresu czasu, w jakim państwa te mogłyby być zaproszone do członkostwa w Pakcie. Nie oznaczało to jednak, że nastąpiła porażka w tej kwestii (Dunn, Zala, 2014, s. 202). Państwa te wprawdzie nie zostały włączone do MAP, jednak otrzymały zapewnienie Sojuszu, że w przyszłości na pewno zostaną zaproszone do pełnego członkostwa w Pakcie $(\mathrm{Bu}$ charest, 2008). W 2009 roku NATO i Ukraina podpisały wspólną deklarację w kwestii zdynamizowania reform na Ukrainie, głównie w sektorze bezpieczeństwa, w celu urzeczywistnienia jej euroatlantyckich aspiracji (Relations with Ukraine).

Po przejęciu władzy przez prezydenta Wiktora Janukowycza (02.2010) Ukraina zaczęła wygaszać swoje aspiracje członkostwa w NATO. Działo się to głównie pod wpływem opozycji ze strony Moskwy, jednak należy też zauważyć, że idea członkostwa w Sojuszu nie miała poparcia większości społeczeństwa Ukrainy. Od lipca 2010 roku Ukraina zaczęła się określać jako „europejskie państwo neutralne”. Nie oznaczało to jednak odcięcia się Kijowa od praktycznej współpracy z NATO (Dunay, 2013, s. 59-60). Sytuacja ponownie się zmieniła po zwycięstwie rozpoczętej w listopadzie 2013 roku i cieszącej się poparciem państw NATO „rewolucji Euromajdanu”. 
Nowe władze Ukrainy, na czele z prezydentem Petro Poroszenko (06.2014-05.2019), przyjęły prozachodni kurs w polityce zagranicznej, który między innymi obejmuje członkostwo w NATO.

\section{Reakcja NATO na politykę militarną Rosji na Ukrainie}

Działania zbrojne Rosji na Ukrainie doprowadziły do jednego z najpoważniejszych kryzysów w Europie od dekad. Od początku 2014 roku Rosja zaczęła wspierać dążenia niepodległościowe separatystów ukraińskich. Przegrupowywała pod granicę z Ukrainą znaczną liczbę żołnierzy i sprzętu wojskowego, co z niepokojem i krytyką obserwowane było przez przywódców NATO. Ponadto wysyłała swoich żołnierzy na terytorium sąsiedniego państwa, do czego nie przyznawała się w pierwszych miesiącach działań hybrydowych. Usprawiedliwiając interwencję na Krymie i w Donbasie Rosja posłużyła się retoryką koncepcji „Odpowiedzialność za ochronę” („Responsibility to Protect - R2P"), w tym ochrony mniejszości rosyjskiej przed działaniami rządu w Kijowie. Zachód odrzucał retorykę Moskwy, że jej działania zbrojne na Ukrainie były analogiczne w stosunku do tych realizowanych przez NATO w Kosowie w 1999 roku (David, 2017, s. 171). Mimo wielu różnic w obu przypadkach nastąpiło zastosowanie siły militarnej bez zgody ze strony Rady Bezpieczeństwa ONZ.

Punktem kulminacyjnym w od lat pogarszających się relacjach między NATO i Rosją była aneksja Krymu z 18 marca 2014 r., która została zdecydowanie potępiona przez przywódców Sojuszu (Snetkov, 2015, s. 163). Po tym wydarzeniu dwustronne relacje nie mogły być już uznawane za partnerskie. W jego konsekwencji NATO całkowicie zawiesiło praktyczną współpracę z Rosją (Flockhart, 2016, s. 154). Niemniej jednak przedstawiciele NATO wyrażali nadzieję na jej odnowienie, argumentując, że przy przestrzeganiu norm i zobowiązań międzynarodowych przez obie strony mogłaby ona mieć strategiczną wartość. Podstawowym warunkiem stawianym Rosji była rezygnacja z Krymu i wycofanie wojsk z obszaru wschodniej Ukrainy. NATO również stanowczo zareagowało na zestrzelenie 17 lipca 2014 r. w obwodzie donieckim samolotu malezyjskich linii lotniczych, w wyniku którego zginęło 298 osób, w tym 154 obywateli Holandii. Po przeprowadzonym śledztwie NATO wezwało Rosję do wzięcia odpowiedzialności za tą katastrofę (Osborne, 2018). Z potępieniem ze strony NATO spotkał się także rosyjski „konwój humanitarny” skierowany na terytorium wschodniej Ukrainy w sierpniu 2014 roku bez zgody władz tego państwa. Sekretarz generalny NATO Anders Fogh Rasmussen uznał, że miał on na celu wsparcie separatystów i w konsekwencji eskalację kryzysu (LoGiurato, 2014). Retoryka NATO była stanowcza, jednak nie miała prowadzić do eskalacji kryzysu. W związku z tym nie pojawiła się groźba interwencji zbrojnej na Ukrainie na rzecz zahamowania agresji Rosji (David, 2016, s. 49).

W dniach 4-5 września 2014 r. odbył się szczyt NATO w Newport w Walii, który koncentrował się na polityce militarnej Rosji wobec Ukrainy. W deklaracji kończącej szczyt uczestnicy określili agresywne działania Rosji przeciwko Ukrainie jako „podważające wizję Europy jedności, wolności i pokoju”. Państwa NATO z całą surowością potępiły nielegalną interwencję zbrojną w tym państwie, wezwały do wycofania 
sił rosyjskich z Ukrainy i terenów przygranicznych oraz ogłosiły, że nie uznają bezprawnej i bezzasadnej aneksji Krymu. Ponadto Sojusz zaapelował do Rosji o wpłynięcie na separatystów działających na Ukrainie, aby zaprzestali destabilizacyjnych działań, które przyczyniają się do pogłębienia kryzysu humanitarnego. Polityka Rosji wobec Ukrainy określona została przez przywódców NATO za sprzeczną z prawem międzynarodowym i podstawowymi zasadami społeczności międzynarodowej, w tym łamiącą zasadę suwerenności państwowej i integralności terytorialnej. W związku z tym poparli oni sankcje nałożone na Rosję przez Unię Europejską, państwa G7 i inne organizacje międzynarodowe. Wobec Ukrainy NATO zapowiedziało z kolei zwiększone wysiłki na rzecz wsparcia reform sektora bezpieczeństwa, aby była zdolna do zapewnienia sobie bezpieczeństwa. Jednocześnie podkreśliło znaczenie współpracy z Ukrainą, określając to państwo ważnym partnerem NATO, który przez lata wnosił ważny wkład w działania Sojuszu (Wales, 2014).

NATO postrzegało działania Rosji na Ukrainie za próbę odbudowy swojej mocarstwowości i stref wpływów przy użyciu siły militarnej i kosztem sąsiadów. Działania Rosji zaniepokoiły nie tylko Ukrainę, ale także państwa Sojuszu, w tym głównie jego wschodniej flanki (Sloan, 2008, s. 78). Szczególnie uzasadnione obawy pojawiły się w państwach bałtyckich, w których, szczególnie na Łotwie i w Estonii, mniejszość rosyjska jest znaczna. Zaczęto się obawiać o przeniesienie działań hybrydowych realizowanych poniżej progu wojny również na terytorium tych państw. Teoretycznie Rosja mogłaby w ten sposób uniknąć rozpoczęcia kolektywnych działań obronnych NATO wynikających z art. 5. traktatu waszyngtońskiego (Williams, 2016, s. 197). Niektórzy obserwatorzy z państw Europy Środkowo-Wschodniej wskazywali nawet, że perspektywicznie Rosja mogłaby się zdecydować nawet na otwarty konflikt z NATO. Scenariusz ten był i nadal jest mało prawdopodobny, jednak od 2014 roku ryzyko jego realizacji znacznie wzrosło.

W związku z działaniami Rosji, NATO zmuszone zostało do zweryfikowania mechanizmów obronnych i zwiększenia zdolności reagowania na zagrożenia różnego typu, w tym działania hybrydowe (Banasik, 2015, s. 56). Pod wpływem nacisków ze strony członków NATO z Europy Środkowo-Wschodniej podjęto szereg działań na rzecz wzmocnienia kolektywnej obrony Paktu. W celu zapewnienia Sojuszowi zdolności szybkiej i zdecydowanej odpowiedzi na nowe zagrożenia bezpieczeństwa spowodowane przez Rosję, podczas szczytu NATO w Newport przyjęto „Plan Działania na rzecz Gotowości” („Readiness Action Plan”) (NATO’s, 2015). W dokumencie przede wszystkim znalazły się postanowienia o wzmocnieniu wschodniej flanki NTO, w tym o (Koziej, Pietrzak, 2014, s. 21-22):

- ciągłej obecności wojsk NATO w regionie, podlegającej cyklicznej rotacji. Na potrzeby przebywających i ćwiczących wojsk miały zostać utworzone odpowiednie bazy logistyczne i sprzętowe;

- rozbudowie w regionie infrastruktury sojuszniczej i rozmieszczeniu baz ze sprzętem NATO, co miało usprawnić możliwość przyjęcia sojuszniczych sił wzmocnienia;

- ustanowieniu dodatkowych ośrodków dowodzenia w regionie wraz z elementami wsparcia i zabezpieczenia oraz rozbudowie, podniesieniu stopnia gotowości i zwiększeniu zdolności w zakresie kolektywnej obrony zlokalizowanego w Szczecinie Dowództwa Wielonarodowego Korpusu Północno-Wschodniego; 
- powołaniu sił natychmiastowego reagowania, które miały być gotowe do podjęcia działania w ciągu kilku dni;

- aktualizacji planów ewentualnościowych i możliwości ich wzmocnienia poprzez przypisanie do nich konkretnych sił;

- zwiększeniu intensywności prowadzonych ćwiczeń wojskowych w regionie.

W dniach 8-9 lipca 2016 r. odbył się szczyt NATO w Warszawie, którego głównym zadaniem było rozwinięcie i implementacja postanowień ze szczytu w Newport, dotyczących wzmocnienia artykułu 5. traktatu waszyngtońskiego. W Deklaracji kończącej szczyt wskazano na agresywne działania Rosji wobec Ukrainy, jak i prowokacje wobec państw peryferyjnych NATO, jako źródło niestabilności w regionie, zasadnicze zagrożenia dla Sojuszu i pokoju w Europie. NATO odpowiedziało na to zagrożenie poprzez rozwijanie zdolności odstraszania i obrony. Zdecydowano o podtrzymaniu zawieszenia współpracy z Rosją, pozostawiając jednocześnie otwarte kanały komunikacji oraz mając nadzieję na perspektywiczną odbudowę relacji. W stosunku do Ukrainy NATO potwierdziło swoje poparcie dla niepodległej, suwerennej, niepodzielnej i stabilnej Ukrainy. Sojusz zapowiedział Całościowy pakiet pomocowy dla Ukrainy (Comprehensive Assistance Package - CAP) w celu wzmocnienia instytucji jej sektora bezpieczeństwa, głównie poprzez doradztwo i wsparcie finansowe. Między innymi zadeklarował pomoc Ukrainie w rozwoju systemów do zwalczania ataków hybrydowych. Jednocześnie państwa NATO opowiedziały się za poszukiwaniem politycznych dróg rozwiązania konfliktu oraz wezwały strony do przestrzegania porozumień mińskich (Warsaw, 2016).

W wymiarze stricte militarnym na szczycie NATO w Warszawie potwierdzono koncepcję wysuniętej obecności wojskowej na wschodniej flance Sojuszu. Postanowiono, że do czerwca 2017 roku na terytorium Litwy, Łotwy, Estonii i Polski pojawią się cztery w pełni operacyjne batalionowe grupy bojowe, które będą tam przybywać na zasadzie rotacji. Grupy obecnie stacjonują w państwach wschodniej flanki pod przewodnictwem państw ramowych, tj. Niemiec na Litwie, Kanady na Łotwie, Wielkiej Brytanii w Estonii i Stanów Zjednoczonych w Polsce (Larsen, 2017, s. 12). W Warszawie zdecydowano również o wzmocnieniu flanki południowo-wschodniej w ramach wsparcia przez NATO tworzenia wielonarodowej brygady w Rumunii. Podtrzymano decyzję z Newport o rozwoju Połączonych Wielonarodowych Sił Zadaniowych o Bardzo Wysokim Stopniu Gotowości (Very High Readiness Joint Task Force - VJTF). Tzw. szpica w sile ok. 5 tys. żołnierzy, wspierana przez jednostki lotnicze, morskie i specjalne, ma być zdolna do rozmieszczenia w przeciągu kilku dni w sytuacji zagrożenia suwerenności państw wschodniej flanki NATO (Lorenz, 2015, s. 1). Potwierdzono również rozwinięcie kadrowe Sił Odpowiedzi NATO (NATO Response Forces - NRF) do stanu 40 tys. żołnierzy. W celu efektywnego przyjmowania obcych wojsk na terytorium państw wschodniej flanki NATO potwierdzono tworzenie Jednostek Integracji sił NATO (NATO Forces Integration Units - NFIU) (Banasik, 2015, s. 35). Podczas szczytu państwa zobowiązały się również do wzmożonych działań na rzecz spełnienia minimalnego dla NATO wymogu finansowania armii na poziomie $2 \%$ PKB.

Na szczycie NATO w Brukseli z 11-12 lipca 2018 r. państwa członkowskie podtrzymały swoje stanowisko w sprawie działań Rosji na Ukrainie oraz postanowienia szczytów z Newport i Warszawy dotyczące wzmocnienia wschodniej flanki Sojuszu. Pozostawiły również w mocy zawieszenie wojskowej i cywilnej współpracy z Rosją, 
przy otwartości na dialog polityczny. Zapewniły również, że NATO nie szuka konfliktu z Rosją, jak również nie stanowi dla niej zagrożenia (Brussels, 2018). Podczas szczytu potwierdzono zobowiązanie z Bukaresztu z 2008 roku, że Ukraina stanie się w przyszłości członkiem Sojuszu. Mimo starań władz Ukrainy nie została ona jednak objęta „Programem rozszerzonych możliwości” (Enhanced Opportunities Program”), a tym bardziej MAP, które w najbliższych latach mogłyby urzeczywistnić te obietnice (Szeligowski, 2018, s. 1). NATO podtrzymało jednak swoje wsparcie dla wzmacniania sektora bezpieczeństwa Ukrainy. Warto odnotować, że podczas szczytu zaistniał spór między delegacją Stanów Zjednoczonych i Niemiec wokół inwestycji „Gazociągu północnego II” („Nord Stream II”). Prezydent Donald Trump (01.2017-...) wyraził zaniepokojenie zaangażowaniem Niemiec i innych państw Europy Zachodniej w projekt „Gazpromu”, uznając, że poważnie godzi on w interesy bezpieczeństwa energetycznego Ukrainy i państw wschodniej flanki Sojuszu.

\section{Zakończenie}

Po zakończeniu zimnej wojny relacje NATO z Rosją i Ukrainą miały charakter preferencyjny, czego przejawem było ustanowienie indywidualnych forów konsultacji i współpracy (Behnke, 2013, s. 157). Zintensyfikowane dążenie Ukrainy do członkostwa w NATO wpłynęło na wzrost obaw i oporu ze strony Rosji (Braun, 2008, s. 58). Gdyby doszło do włączenia Ukrainy, a przy okazji Gruzji, do NATO, Zachód zyskałby znaczną geostrategiczną przewagę nad Rosją. Pozwoliłoby mu to oskrzydlić Rosję także od strony południowo-zachodniej (Bandeira, 2017, s. 63). Zniweczyłoby również plan Moskwy odbudowy mocarstwowości w oparciu o strefy wpływów na obszarze „bliskiej zagranicy". Z tego względu Rosja zdecydowała się na zdecydowane działania, aby nie dopuścić do realizacji tego niekorzystnego dla niej scenariusza. Konflikt na Ukrainie nie jest bowiem tylko rywalizacją między dwoma państwami. Jest to napastnicza próba zahamowania przez Rosję rozprzestrzeniania wpływów NATO u jej granic (Adamsky, 2016, s. 129). Oceniając tę kwestię z perspektywy teorii realistycznych działanie Rosji było naturalną reakcją, w związku z czym główną odpowiedzialnością za kryzys na Ukrainie należałoby obarczyć Zachód (Mearsheimer, 2014).

Status quo między NATO i Rosją jest zachwiany, co może prowadzić do coraz poważniejszej konfrontacji. Napięcia we wzajemnych relacjach znacząco wzrosły po aneksji Krymu przez Rosję i wsparciu przez nią działań separatystycznych w Donbasie. Wzmacnianie przez NATO po 2014 r. wschodniej flanki powoduje intensyfikację zbrojeń Rosji na zachodzie kraju i próbę włączenia w te działania Białorusi. Oprócz tego istnieje jeszcze szereg innych źródeł napięć, w tym program antyrakietowy NATO, inne podejście do rozwiązania szeregu kryzysów na świecie, czy odmienne postrzeganie kwestii demokracji i praw człowieka (Fedorov, 2010, s. 126).

Po zimnej wojnie NATO koncentrowało się na przeciwdziałaniu tzw. nowym zagrożeniom, w tym zwalczaniu terroryzmu międzynarodowego, proliferacji broni masowego rażenia, czy wygaszaniu kryzysów lokalnych i regionalnych o różnym podłożu. W związku z tym Sojusz skupiał się na rozwoju zdolności w zakresie reagowania kryzysowego poza obszarem mandatowym (Keller, 2017, s. 59). Ponieważ Rosja dąży do siło- 
wej zmiany granic w Europie, NATO zmuszone jest do ponownego skoncentrowania się na funkcji, do jakiej zostało pierwotnie powołane, tj. kolektywnej obrony członków i odstraszania potencjalnych agresorów (van Apeldoorn, de Graaff, 2016, s. 220). Obecnie podejmuje ono działania na rzecz praktycznego wzmocnienia gwarancji bezpieczeństwa wynikających z artykułu 5. traktatu waszyngtońskiego, głównie wobec państw wschodniej flanki Sojuszu (Hyde-Price, 2016, s. 43). Co ważne w działania te zaangażowała się najpotężniejsza w NATO armia amerykańska, która przed kryzysem sukcesywnie redukowała swoją obecność wojskową w Europie (David, 2017, s. 176).

Obecnie istnieje pewne ryzyko, że Rosja może próbować przenieść działania hybrydowe na terytorium państw bałtyckich. Minimalizując wykorzystanie czynnika militarnego mogłaby liczyć na to, że NATO nie zdecyduje się na odpowiedź militarną w ramach kolektywnej samoobrony (Adamsky, 2016, s. 133-134). Prowokacyjne działania Rosji wobec państw członkowskich Sojuszu, nie tylko tych zlokalizowanych na jego wschodniej flance, są przejawem testowania solidarności Paktu i gotowości kolektywnego reagowania. W dużej mierze to od samego NATO zależy, jak daleko Rosja będzie w stanie się posunąć wobec jego poszczególnych członków. Nie można całkowicie wykluczyć również konfrontacji zbrojnej na większą skalę między NATO i Rosją. W ostatnich latach Rosja szybko modernizuje swoją armię i prowadzi ćwiczenia wojskowe na szeroką skalę. We władzach w Moskwie duże znaczenie mają osoby wywodzące się z szeroko pojmowanego sektora bezpieczeństwa, w tym sam prezydent Władimir Putin (Chenoy, Kumar, 2017, s. 220). Ponadto w dokumentach strategicznych Rosji i przestrzeni medialnej dominuje wroga, antynatowska narracja.

Jeśli chodzi o stosunki NATO z Ukrainą, to szanse na pełne członkostwo tego państwa w strukturach Sojuszu znacząco zmalały po 2014 roku. Sojusz nie przyjmie do swojego grona zdestabilizowanej i skonfliktowanej z Rosją Ukrainy. Musiałby ją bowiem objąć kolektywnymi gwarancjami bezpieczeństwa, co oznaczałoby wejście w otwarty konflikt z Rosją (David, 2016, s. 49). NATO zależy na ustabilizowaniu sytuacji na Ukrainie, ugruntowaniu w niej wartości demokracji i państwa prawa oraz normalizacji relacji z Rosją (Treverton, 2016, s. 53). Dopiero wtedy państwa członkowskie byłyby ewentualnie gotowe przyjąć Ukrainę do Paktu. Potencjalnie dałoby to korzyści obu stronom. Dla Ukrainy przede wszystkim oznaczałoby to objęcie kolektywnymi gwarancjami bezpieczeństwa. Ponadto pozwoliłoby to jej partycypować w pozyskiwaniu i korzystaniu ze wspólnych zdolności, na przykład w zakresie wywiadu, czy działań antyterrorystycznych (Simoni, 2013, s. 54-55). Z kolei Ukraina jako członek NATO mogłaby wnosić ważny wkład w rozwiązywanie międzynarodowych kryzysów. Gotowość do takiego działania pokazała przez lata angażując się w operacje wojskowe Sojuszu (Sloan, 2008, s. 80).

\section{Bibliografia}

Aaltola M., Käpylä J., Vuorisalo V. (2014), The Challenge of Global Commons and Flows for US Power. The Perils of Missing the Human Domain, Routledge, London-New York.

Adamsky D. (2016), Change and continuity in Russian perceptions of the United States, w: US Foreign Policy and Global Standing in the $21^{\text {st }}$ Century. Realities and Perceptions, red. E. Inbar, J. Rynhold, Routledge, London-New York. 
Apeldoorn B. van, Graaff N. de (2016), American Grand Strategy and Corporate Elite Networks. The Open Door since the End of the Cold War, Routledge, London-New York.

Banasik M. (2015), NATO w świetle postanowień szczytu w Newport, „Kwartalnik Bellona”, nr 3.

Bandeira L. A. (2017), The Second Cold War. Geopolitics and Strategic Dimensions of the USA, Springer, New York.

Behnke A. (2013), NATO's Security Discourse after the Cold War. Representing the West, Routledge, London-New York.

Bouchet N. (2015), Democracy Promotion as US Foreign Policy. Bill Clinton and democratic enlargement, Routledge, London-New York.

Braun A. (2008), Enlargement and the perils of containment, w: NATO-Russia Relations in the Twenty-First Century, red. A. Braun, Routledge, London-New York.

Brussels Summit Declaration Issued by the Heads of State and Government participating in the meeting of the North Atlantic Council in Brussels 11-12 July 2018 (2018), Brussels, 12 July, https://www.nato.int/cps/en/natohq/official_texts_156624.htm, 11.09.2018.

Bucharest Summit Declaration Issued by the Heads of State and Government participating in the meeting of the North Atlantic Council in Bucharest on 3 April 2008 (2008), Bucharest, 3 April, https://www.nato.int/cps/en/natolive/official_texts_8443.htm, 11.09.2018.

Charter on a Distinctive Partnership between NATO and Ukraine between the North Atlantic Treaty Organization and Ukraine (1997), 9 July, https://www.nato.int/cps/en/natohq/official_ texts_25457.htm, 11.09.2018.

Chenoy A. M., Kumar R. (2017), Re-emerging Russia. Structures, Institutions and Processes, Palgrave Macmillan, New York.

Cornell P. (2013), NATO and energy security: defining a role, w: Understanding NATO in the $21^{\text {st }}$ Century. Alliance strategies, security and global governance, red. G. P. Herd, J. Kriendler, Routledge, London-New York.

David M. (2017), US-Russia relations in Obama's second term: a damage limitation exercise, w: The Obama Doctrine. A legacy of continuity in US foreign policy?, red. M. Bentley, J. Holland, Routledge, London-New York.

David S. (2016), Obama: the reluctant realist, w: US Foreign Policy and Global Standing in the $21^{\text {st }}$ Century. Realities and Perceptions, red. E. Inbar, J. Rynhold, Routledge, London-New York.

Dumbrell J. (2009), Clinton's Foreign Policy. Between the Bushes, 1992-2000, Routledge, LondonNew York.

Dunay P. (2013), NATO enlargement: close to the end?, w: Understanding NATO in the $21^{\text {st }}$ Century. Alliance strategies, security and global governance, red. G. P. Herd, J. Kriendler, Routledge, London-New York.

Dunn D. H., Zala B. (2014), Transatlantic relations and US foreign policy, w: Obama and the World. New directions in US foreign policy. Second edition, red. I. Parmar, L. B. Miller, M. Ledwidge, Routledge, London-New York.

Fedorov Y. E. (2010), The return of history: hard security issues in the Russia-Europe relationship, w: Russia and Europe. Building bridges, digging trenches, red. K. Engelbrekt, B. Nygren, Routledge, London-New York.

Flockhart T. (2016), Understanding NATO through constructivist theorizing, w: Theorising NATO. New perspectives on the Atlantic alliance, red. M. Webber, A. Hyde-Price, Routledge, London-New York.

Founding Act on Mutual Relations, Cooperation and Security between NATO and the Russian Federation signed in Paris (1997), Paris, 27 May, http://www.nato.int/cps/en/natohq/official_ texts_25468.htm, 11.09.2018. 
Gardner H. (2005), American Global Strategy and the "War on Terrorism", Routledge, LondonNew York.

Hallams E. (2010), The United States and NATO since 9/11. The transatlantic alliance renewed, Routledge, London-New York.

Hansen B., Toft P., Wivel A. (2009), Security Strategies and American World Order. Lost Power, Routledge, London-New York.

Herd G. P. (2013), NATO partnerships: for peace, combat, and soft balancing?, w: Understanding NATO in the $21^{\text {st }}$ Century. Alliance strategies, security and global governance, red. G. P. Herd, J. Kriendler, Routledge, London-New York.

Hyde-Price A. (2016), NATO and the European security system: a neorealist analysis, w: Theorising NATO. New perspectives on the Atlantic alliance, red. M. Webber, A. Hyde-Price, Routledge, London-New York.

Interfax-Ukraine (2011), Poll: Most Crimean residents consider Ukraine their motherland, "Kyiv Post" 11 April 2011, https://www.kyivpost.com/article/content/ukraine-politics/poll-mostcrimean-residents-consider-ukraine-their-102113.html?cn-reloaded=1, 11.09.2018.

Kaplan L. S. (2004), NATO Divided, NATO United The Evolution of an Alliance, Praeger Publishers, Westport.

Keller P. (2017), Divided by geography? NATO's internal debate about the eastern and southern flanks, w: NATO and Collective Defence in the $21^{\text {st }}$ Century. An Assessment of the Warsaw Summit, red. K. Friis, Routledge, London-New York.

Koziej S., Pietrzak P. (2014), Szczyt NATO w Walii: uwarunkowania, rezultaty, wnioski dla Polski, „Bezpieczeństwo Narodowe”, nr 3.

Lagadec E. (2012), Transatlantic Relations in the 21 $1^{\text {st }}$ Century. Europe, America and the rise of the rest, Routledge, London-New York.

Larsen J. A. (2017), NATO's responses to Russian belligerence: an overview, w: NATO and Collective Defence in the $21^{\text {st }}$ Century. An Assessment of the Warsaw Summit, red. K. Friis, Routledge, London-New York.

Leichtova M. (2016), Misunderstanding Russia. Russian Foreign Policy and the West, Routledge, London-New York.

Lindley-French J., Macfarlane N. (2007), The North Atlantic Treaty Organization. The Enduring Alliance, Routledge, London-New York.

LoGiurato B. (2014), NATO: Russia Just Significantly Escalated The Crisis In Ukraine, 22 August, https://www.businessinsider.com/russian-invasion-of-ukraine-nato-putin-obama-2014$8 ? \mathrm{IR}=\mathrm{T}, 11.09 .2018$.

Lorenz W. (2015), 2016 - Szczyt strategicznej adaptacji NATO, „Biuletyn PISM” 2015, nr 56 (1293), https://www.pism.pl/files/?id_plik=19966, 11.09.2018.

MacFarlane S. N. (2008), Russia, NATO enlargement and the strengthening of democracy in the European space, w: NATO-Russia Relations in the Twenty-First Century, red. A. Braun, Routledge, London-New York.

Mearsheimer J. J. (2014), Why the Ukraine Crisis Is the West's Fault. The Liberal Delusions That Provoked Putin, ,Foreign Affairs”, September/October, https://www.foreignaffairs.com/articles/russia-fsu/2014-08-18/why-ukraine-crisis-west-s-fault, 30.04.2019.

NATO's Readiness Action Plan (2015), May, http://www.nato.int/nato_static_fl2014/assets/pdf/ pdf_2015_05/20150508_1505-Factsheet-RAP-en.pdf, 11.09.2018.

Orfy M. M. (2011), NATO and the Middle East. The geopolitical contexts post-9/11, Routledge, London-New York.

Osborne S. (2018), Flight MH17 shot down by Russian military-sourced missile, investigators conclude, “The Independent” 24 May 2018, https://www.independent.co.uk/news/world/europe/ 
mh17-missile-ukraine-2014-russia-military-netherlands-deaths-investigation-a8366721. html, 11.09.2018.

Ponsard L. (2007), Russia, NATO and Cooperative Security. Bridging the Gap, Routledge, LondonNew York.

Relations with Russia, https://www.nato.int/cps/en/natolive/topics_50090.htm, 11.09.2018.

Relations with Ukraine, https://www.nato.int/cps/en/natolive/topics_37750.htm\#, 11.09.2018.

Simoni S. (2013), Understanding Transatlantic Relations. Whither the West?, Routledge, LondonNew York.

Sloan S. R. (2008), NATO beyond Russia, w: NATO-Russia Relations in the Twenty-First Century, red. A. Braun, Routledge, London-New York.

Snetkov A. (2015), Russia's Security Policy under Putin. A critical perspective, Routledge, LondonNew York.

Szeligowski D. (2018), Perspektywy wspótpracy NATO-Ukraina, „Biuletyn PISM”, nr 99 (1672), https://www.pism.pl/files/?id_plik=24676, 11.09.2018.

Terzuolo E. (2006), NATO and Weapons of Mass Destruction. Regional alliance, global threats, Routledge, London-New York.

The Alliance's Strategic Concept Approved by the Heads of State and Government participating in the meeting of the North Atlantic Council in Washington D.C. (1999), Washington D.C., 4 April, https://www.nato.int/cps/en/natohq/official_texts_27433.htm, 11.09.2018.

Treverton G. F. (2016), A Post-Modern Transatlantic Alliance, w: Hard Power, Soft Power and the Future of Transatlantic Relations, red. T. L. Ilgen, Routledge, London-New York.

Wales Summit Declaration Issued by the Heads of State and Government participating in the meeting of the North Atlantic Council in Wales (2014), Newport, 5 September, https://www.nato.int/ cps/ic/natohq/official_texts_112964.htm, 11.09.2018.

Warsaw Summit Communique Issued by the Heads of State and Government participating in the meeting of the North Atlantic Council in Warsaw 8-9 July 2016 (2016), Warsaw, 9 July, https://www.nato.int/cps/ic/natohq/official_texts_133169.htm, 11.09.2018.

Webber M. (2016), Is NATO a theory-free zone?, w: Theorising NATO. New perspectives on the Atlantic alliance, red. M. Webber, A. Hyde-Price, Routledge, London-New York.

Widmaier W. W. (2015), Presidential Rhetoric from Wilson to Obama. Constructing crises, fast and slow, Routledge, London-New York.

Williams M. J. (2016), NATO and the risk society: modes of alliance representation since 1991, w: Theorising NATO. New perspectives on the Atlantic alliance, red. M. Webber, A. Hyde-Price, Routledge, London-New York.

Zięba R. (2013), Polityka zagraniczna Polski w strefie euroatlantyckiej, Wydawnictwa Uniwersytetu Warszawskiego, Warszawa.

\section{Streszczenie}

Przedmiotem analizy są okoliczności i postawa NATO wobec polityki militarnej Rosji na Ukrainie. W artykule omówiono zagadnienia takie jak relacje między NATO i Rosją po zimnej wojnie, relacje między NATO i Ukrainą po zimnej wojnie oraz reakcja Sojuszu na politykę militarną Rosji na Ukrainie. Artykuł ma dać odpowiedź na pytanie czy reakcja NATO była odpowiednia i wystarczająco zdecydowana, żeby zabezpieczyć przed Rosją państwa wschodniej flanki NATO, skutecznie zniechęcić ją do prowokacji wobec członków Sojuszu oraz zmusić do zmiany polityki wobec Ukrainy? Działania podjęte przez NATO w odpowiedzi na politykę militarną Rosji na Ukrainie koncentrują się na wzmocnieniu bez- 
pieczeństwa i potwierdzeniu gotowości do kolektywnej obrony członków Sojuszu. Pomoc Ukrainie ma charakter wtórny i ograniczony, a jej skala jest niewystarczająca, aby zmusić Rosję do zmiany polityki wobec tego państwa. Wydarzenia na Ukrainie doprowadziły do kryzysu w relacjach między Rosją i NATO, jak również zmniejszyły szansę Ukrainy na przyjęcie do Sojuszu.

Slowa kluczowe: NATO, Rosja, Ukraina, aneksja Krymu, wojna w Donbasie

\title{
Circumstances and attitude of NATO towards Russia's military policy in Ukraine
}

\begin{abstract}
Summary
The subject of the analysis are the circumstances and attitude of NATO towards the military policy of Russia in Ukraine. The article discusses issues such as relations between NATO and Russia after the Cold War, relations between NATO and Ukraine after the Cold War and the Alliance's response to Russia's military policy in Ukraine. The article is intended to answer the question of whether NATO's response was appropriate and sufficiently determined to protect NATO's eastern flank states from Russia, effectively discourage it from provoking members of the Alliance and force it to change its policy towards Ukraine? Actions taken by NATO in response to Russia's military policy in Ukraine focus on strengthening security and confirming the readiness to collective defense of Alliance members. Assistance to Ukraine is of a secondary and limited nature, and its scale is insufficient to force Russia to change its policy towards that country. The events in Ukraine led to a crisis in relations between Russia and NATO, as well as reduced the chances of Ukraine to join the Alliance.
\end{abstract}

Key words: NATO, Russia, Ukraine, annexation of Crimea, war in Donbass 